\title{
Intelligent learning environment for better student's academic performance
}

\author{
Anca - Elena Vișan ${ }^{1 *}$, Mihai - Victor Zerbes ${ }^{1}$, Ștefania Kifor $^{2}$ \\ ${ }^{1}$ Lucian Blaga University of Sibiu, Engineering Faculty, Industrial Engineering and Management \\ Department, Emil Cioran Street, No. 4, 550025 Sibiu, Romania \\ ${ }^{2}$ Teacher Education Department, Social and Human Science Faculty, 5-7 Victoriei Blv.
}

\begin{abstract}
In this paper, the authors aim to develop an intelligent learning environment model designed to improve students' academic performance. Methodology: Referring to the litarature, the authors identified and analyzed a number of relevant issues that influence the specific components of an intelligent learning environment. These aspects were quantified using performance indicators defined on the basis of the specific objectives of each aspect chosen. Results: Following the analysis, the authors developed a model of intelligent learning space, and for its representation, we used conceptual modeling. Conclusions: Finally, the authors propose the prevalidation of the model using the dynamic modeling process and then the model will be piloted for final validation in both physical and virtual environment. These aspects are proposed because in the present study, the model was validated only based on the results from studies in scientific literature.
\end{abstract}

\section{Introduction}

Intelligent learning environments are spaces that can be created to encourage interaction and participation, reduce the barrier between teacher and student, in order to help interactive learning activities in the classroom.[1-4].In other words, intelligent learning environments are spaces where technology and environmental factors are taken into account in order to improve students' academic performance $[5,6]$.In the last ten years, the literature has increased again in relation to learning environments such as the evaluation of libraries after their occupancy or especially qualitative studies $[5,6]$.

While active learning pedagogy can certainly be applied in traditional classrooms with fixed places, a good substitute for this pedagogy would be an intelligent learning environment [7]. In an effort to combine architectural design with best practices in learning education, many researchers have identified how learning environments can be imagined differently to maintain interactive learning and enhance its practical impact on students' academic performance [7].In this paper, the authors aim to develop an intelligent learning environment model designed to improve students' academic performance.

\subsection{Problem statement}

The requirement to transform education and evolve learning spaces has been a hotly debated topic for years, and today the learning environment in higher education is constantly changing, but student academic performance has remained unchanged. The

"Corresponding author: anca.visan@ulbsibiu.ro 
intelligent environment has been seen and explained as a general idea that unites the aspects and performances of learning with those of social learning, supported by digital content and interactive services [8], so that they are aware of every influence that man has with the environment in order to respond to his or her individual needs in all kinds of situations [9].

\section{Literature review}

According to the literature, emerging research has focused on integrating the relative study of learning environments, drawing academic and institutional attention to the effects of physical space and its accessories on learning and students.

\subsection{Definitions of an intelligent learning environment}

An intelligent learning environment is perceived by other researchers as follows:

- Intelligent learning environmets deliberately and strategically involve the use of technology in learning environments in order to enable a significant impact on the academic performance of students[10].

- Identified as a learning or activity space that can capture laerning scenarios, identify student characteristics, provide appropriate resources and practical interactive tools, automatically record the learning outcomes to promote an effective cause [11].

- An intelligent learning environments needs to be enriched with digital, adaptable and awareparts to encourage effective learning [12].

- Other authors also see an intelligent learning environment based on the personalization of teaching and adaptive learning through technology in order to achieve better academic performance of the learner[13-15].

Hence, a intelligent learning environment must consider adjusting all activities in order to give an optimum alternative to the students.

\subsection{Theoretical framework}

The paradigm of traditional learning has been criticized because it is too artificial and no longer keeps up with the current requirements, as the field of technology is developing more and more[16] .

In view of the learning perspective, an intelligent learning environment that can own learning services depending on location, time and other requiremets [17-18].

From a technical point of view, the intelligent learning environment combines with the help of information technology both physical and online learning environments [19].

Intelligent technology - enabled learning environmets should not only enable students to use the necessary resources so that they can create an interdependence with the learning pattern anywhere, anytime, but also provide them with all the suport and resources they need to learn [16]. Based on the support different technologies, we believe that the goal of intelligent learning environments is to provide comprehensive and personalized personalization and perfect learning experience for students. Therefore, we have identified ten key features of intelligent learning environmets in Table 1 [16]. 
Table 1. Main characteristics of intelligent learning environments[16]

\begin{tabular}{|c|l|l|}
\hline No.crt. & Key features & Description \\
\hline 1 & Place -consciously & Identify the student`s location in real time \\
\hline 2 & Context - conscious & Discover different scenarios and activity information \\
\hline 3 & Socially Aware & Feel the social relationship \\
\hline 4 & Interoperability & $\begin{array}{l}\text { Set the standard between different resources, services and } \\
\text { platforms }\end{array}$ \\
\hline 5 & Perfect connection & Provide continuous services when a device connects \\
\hline 6 & Adaptability & $\begin{array}{l}\text { Push the learning resource according to learning access, } \\
\text { preference and demand }\end{array}$ \\
\hline 8 & Omnipresent & $\begin{array}{l}\text { Provide a visual and transparent way to access learning } \\
\text { resources and services for students }\end{array}$ \\
\hline 9 & Natural interaction & $\begin{array}{l}\text { Collect and analyze learning path data, then provide } \\
\text { appropriate assessment, suggestions and on-demand } \\
\text { services }\end{array}$ \\
\hline 10 & High engagement & $\begin{array}{l}\text { Transfer the senses of multimodal interaction including } \\
\text { facial position and expression recognition }\end{array}$ \\
\hline $\begin{array}{l}\text { Immerse yourself in the learning experience of } \\
\text { multidirectional interaction in a technology - rich } \\
\text { environment. }\end{array}$ \\
\hline
\end{tabular}

Other researchers believe that fully conceptualizing an intelligent environment identifies the interconnected elements that are needed to define such an environment: technology, environmental factors and processes [11]. Table 2 presents these elements and their basic components.

Table 2. The size and categories of features in an intelligent learning environment[11]

\begin{tabular}{|c|c|c|}
\hline Environment & Technology & Processes \\
\hline Architecture & $\begin{array}{l}\text { Hardware and physical } \\
\text { technology }\end{array}$ & $\begin{array}{l}\text { Processes and } \\
\text { supported fucntions }\end{array}$ \\
\hline \multirow{2}{*}{$\begin{array}{l}\text { Environmental factors: } \\
\text { temperature, humidity, } \\
\text { lighting, air quality,noise or } \\
\text { echo, power consumption }\end{array}$} & Software & Learning content \\
\hline & ICT and New paradigms & $\begin{array}{l}\text { Processes performed by actors } \\
\text { (students, parents, teachers) }\end{array}$ \\
\hline
\end{tabular}

Technological solutions - the most used solution today is cloud computing because it facilitates teamwork and access at the information for the students and teachersat all times [11].

Environmental conditions - The classroom environment affects the student's progress, mood, comfort and ability to concentrate, resulting in poor academic performance. From the perspective of an intelligent class, it is necessary to control lighting, air quality and acoustics [11].

Processes implemented -Various stakeholder approaches have been published, including intelligent classrooms based on constructivist epistemology [11].

Currently, on current trends, teaching and learning in intelligent classrooms tend towards cooperative cooperation and collaboration between students, learning and practical learning [11]. Also in intelligent learning environments, it is important to take into account learners' opinions and emotional states in order to change and improve the learning content, as these opinions can help teachers understand student behavior [20,21].

\section{Methodology}

As mentioned in the introduction, in this paper we aimed to develop a model of intelligent learning environment that aims to improve the academic performance of students.. The 
study began with a systematic review of the current guidelines for creating intelligent environments. The methodology chosen for this research included:

- Data collection and creative analysis based on systematic approach

- Quantification of relevant aspects using performance indicators defined on the basis of specific objectives for each selected aspect.

\subsection{Data collection and creative analysis based on a systematic approach}

In relation to the literature, the authors identified and analyzed a number of relevant topics that influence the specific components of an intelligent learning environment.In this sense, we have developed a framework for the systematic creative analysis of these dimenions. The framework for the systematic analysis of these dimenions includes the following headings:

- Identified list of main features;

- $\quad$ Establishing the specific objectives related ti each chosen aspect;

- Quantification of specific objectives using performance indicators

The results of the systematic creative analysis performed based on the analysis of the literature, for each of the three dimensions identified, the specific objectives and performance indices are presented in tables: $3 ; 4 ; 5$.

Table 3. Aspects specific to the environmetal dimension [11]

\begin{tabular}{|l|l|l|}
\hline Specific aspects & Specific objectives & Performance indicator \\
\hline Temperature, & $\begin{array}{l}\text { Temperature control that } \\
\text { ensures the right } \\
\text { parameters for learning }\end{array}$ & Relevant specifications from students \\
\hline Humidity & Intelligent oxigen control & Relevant specifications from students \\
\hline Noise or echo & $\begin{array}{l}\text { Acoustics adapted to } \\
\text { spaces }\end{array}$ & Relevant specifications from students \\
\hline Electricity consumption & $\begin{array}{l}\text { High performance } \\
\text { daylight combined with } \\
\text { artificial light }\end{array}$ & Relevant specifications from students \\
\hline Cognitive processes & $\begin{array}{l}\text { The colors of the room } \\
\text { adapt to the needs of the } \\
\text { students depending on the } \\
\text { type of activity and the } \\
\text { needs of the students }\end{array}$ & \\
\hline
\end{tabular}

Table 4. Aspects specific to the processes learning dimension [11]

\begin{tabular}{|l|l|l|}
\hline Specific aspects & Specific objectives & Performance indicator \\
\hline $\begin{array}{l}\text { Process and system-supported } \\
\text { functions }\end{array}$ & $\begin{array}{l}\text { Share and help shape the } \\
\text { exchange of knowledge }\end{array}$ & Relevant specifications from students \\
\hline Learning content & $\begin{array}{l}\text { Collaboration and } \\
\text { cooperation between } \\
\text { students }\end{array}$ & Relevant specifications from students \\
\cline { 2 - 4 } & $\begin{array}{l}\text { Creativity and knowledge } \\
\text { management }\end{array}$ & Relevant specifications from students \\
\hline Processes carried out by actors & $\begin{array}{l}\text { Learning in resurce - } \\
\text { efficient spaces leads to } \\
\text { better academic } \\
\text { performance }\end{array}$ & Relevant specifications from teachers \\
\hline
\end{tabular}




\begin{tabular}{|l|l|l|}
\hline & Collaborative learning & Relevant specifications from students \\
\cline { 2 - 3 } & $\begin{array}{l}\text { Learning content created } \\
\text { by students }\end{array}$ & Relevant specifications from students \\
\hline
\end{tabular}

Table 5.Aspects specific to the technology dimension [11]

\begin{tabular}{|l|l|l|}
\hline Specific aspects & Specific objectives data & Performance indicator \\
\hline Software & $\begin{array}{l}\text { Collaborative selevant specifications from students } \\
\text { software tools }\end{array}$ & Relevant specifications from students \\
\hline $\begin{array}{l}\text { Hardware and physical } \\
\text { technology }\end{array}$ & Acces to knowledge & Relevant specifications from students \\
\cline { 2 - 3 } & Virtual science labs & $\begin{array}{l}\text { Relevant specifications from students } \\
\text { and teachers }\end{array}$ \\
\cline { 2 - 3 } & $\begin{array}{l}\text { Sensors for measuring } \\
\text { biodiversity }\end{array}$ & $\begin{array}{l}\text { Relevant specifications from students } \\
\text { and teachers }\end{array}$ \\
\hline ICT and New paradigms & \multicolumn{2}{|l}{} \\
\hline
\end{tabular}

\section{Result}

Following the analysis, we developed a model of intelligent learning space and for its representation, we used conceptual modeling. For it's reprezentation we used the IDEFØ method (Integrated Definition).

\subsection{Elaboration of the conceptual model of intelligent learning environment}

The conceptual model developed (A0) for the intelligent learning environment presented in the figure 1, is broken down into 4 levels of detail as follows:

A1 - Planning to achieve an intelligent learning environment:

- Launching the development of intelligent learning environment;

- Team training;

- Elaboration of planning documentations.

A2 - Designing the intelligent learning environment:

- Elaboration of project documentation;

- Bibliographic research;

- Analysis of aspects relevant to the prototype.

A3 - Prototype execution:

- Prototype execution;

- Performing checks and tests;

- Develop a standard for the new model of intelligent learning environment.

A4 - Prototype validation :

- Prototype validation;

- Elaboration of the documentations for the validated prototype;

- Launching the new intelligent learning model.

The conceptual model developed (A0) for the intelligent learning environment, also has defined:

Purpose: Protyping an intelligent learning environment model;

Objective: Improving the academic performance of students;

Performance indicator:Current academic results of students/ Future academic performance of students. 


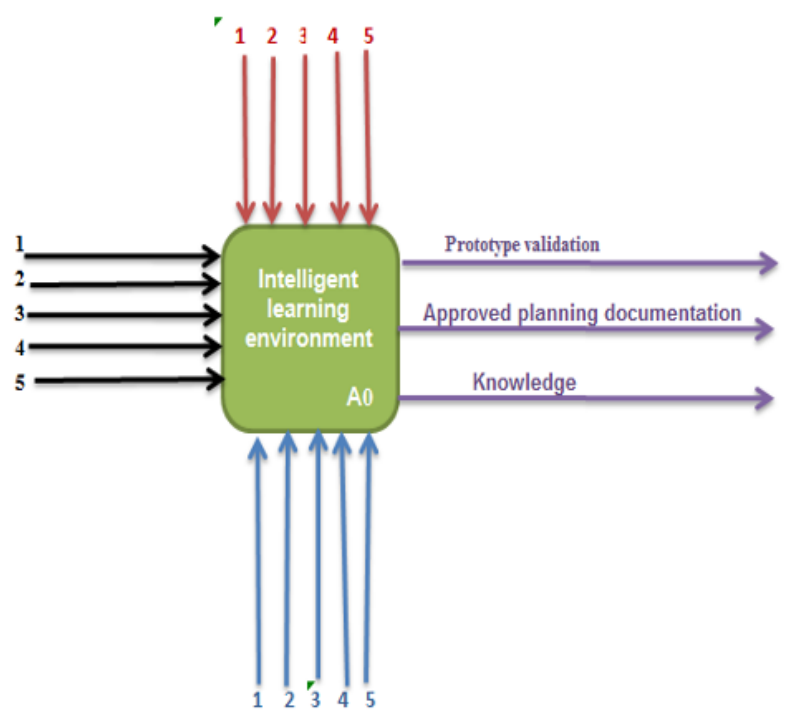

\section{Legends}

No. Input data

crt.

1 Student requirements

2 Teacher requirements

3 New ideas from students and teachers

4 Results of Other regulations specialized studies

5

\section{Control elements}

Legal regulations

Internal regulations

Managerial policies

Management systems

Parental $\quad$ Management systems
requirements

\section{Mechanisms}

Procedures / instructions

Personal

Material resources

Financial resources

Infrastructure / equipment

Fig.1. The Conceptual Model of the Intelligent Learning Environment

The representation of each stage ( A1 to A4 ) was modeled as shown in figure 2. 


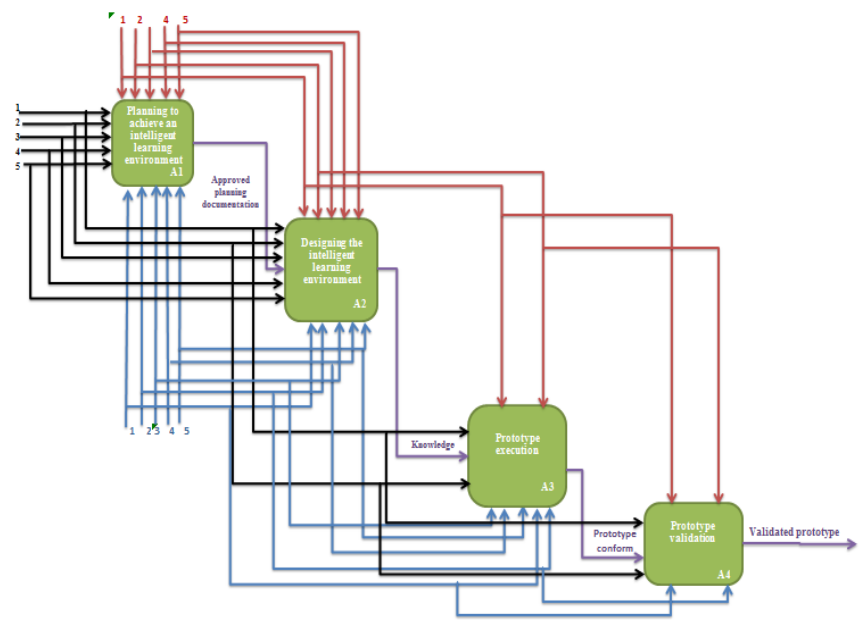

\section{Legends}

\section{No.crt. Input data}

2

3

4

5 teachers
Student requirements

Teacher requirements

New ideas from students and

Results of specialized studies

Parental requirements

\section{Control elements}

Legal regulations Internal regulations

Managerial policies

Other regulations

Management systems

\section{Mechanisms}

Procedures / instructions

Personal

Material resources

Financial resources

Infrastructure / equipment

Fig. 2. Representation of the stages that make up the conceptual model

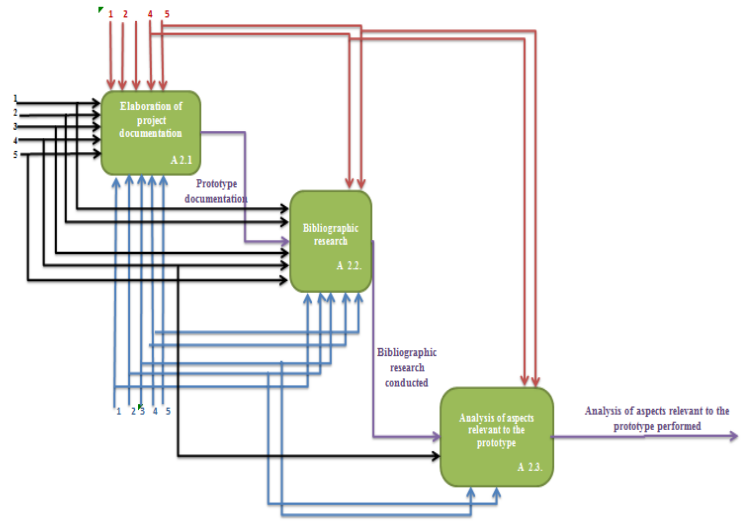

\section{Legends}

\section{No.crt. Input data}

1

2

3

4

5 teachers

\section{Student requirements}

Teacher requirements

New ideas from students and

Results of specialized studies

Parental requirements

\section{Control elements}

Legal regulations

Internal regulations

Managerial policies

Other regulations

Management systems

Fig. 3. Planning to achieve an intelligent learning environment

\section{Mechanisms}

Procedures

instructions

Personal

Material resources

Financial resources

Infrastructure

equipment 
Each of these steps, being approached as processes were decomposed into subprocesses and then modeled as follows:

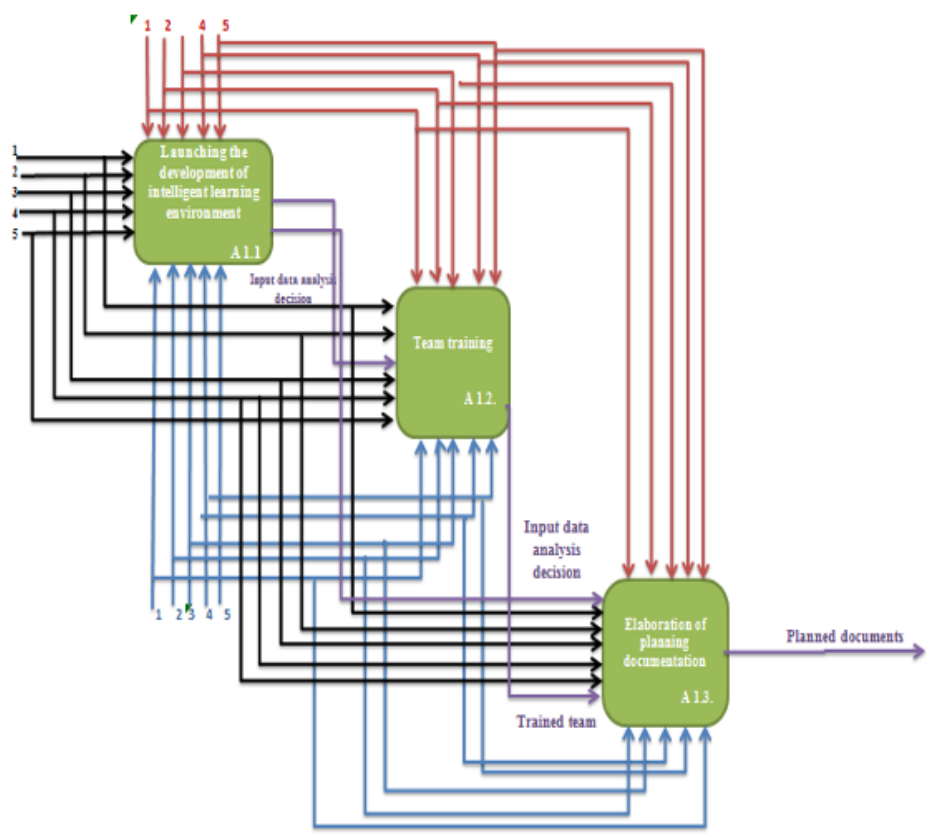

\section{Legends}

$\begin{array}{llll}\text { No.crt. } & \text { Input data } & \text { Control elements } & \text { Mechanisms } \\ 1 & \text { Student requirements } & \text { Legal regulations } & \text { Procedures / instructions } \\ 2 & \text { Teacher requirements } & \text { Internal regulations } & \text { Personal } \\ 3 & \begin{array}{l}\text { New ideas from students and } \\ \text { teachers }\end{array} & \text { Managerial policies } & \text { Material resources } \\ & \text { Results of specialized studies } & \text { Other regulations } & \text { Financial resources } \\ 5 & \text { Parental requirements } & \text { Management systems } & \text { Infrastructure / equipment }\end{array}$

Fig. 4. Designing the intelligent learning environment 


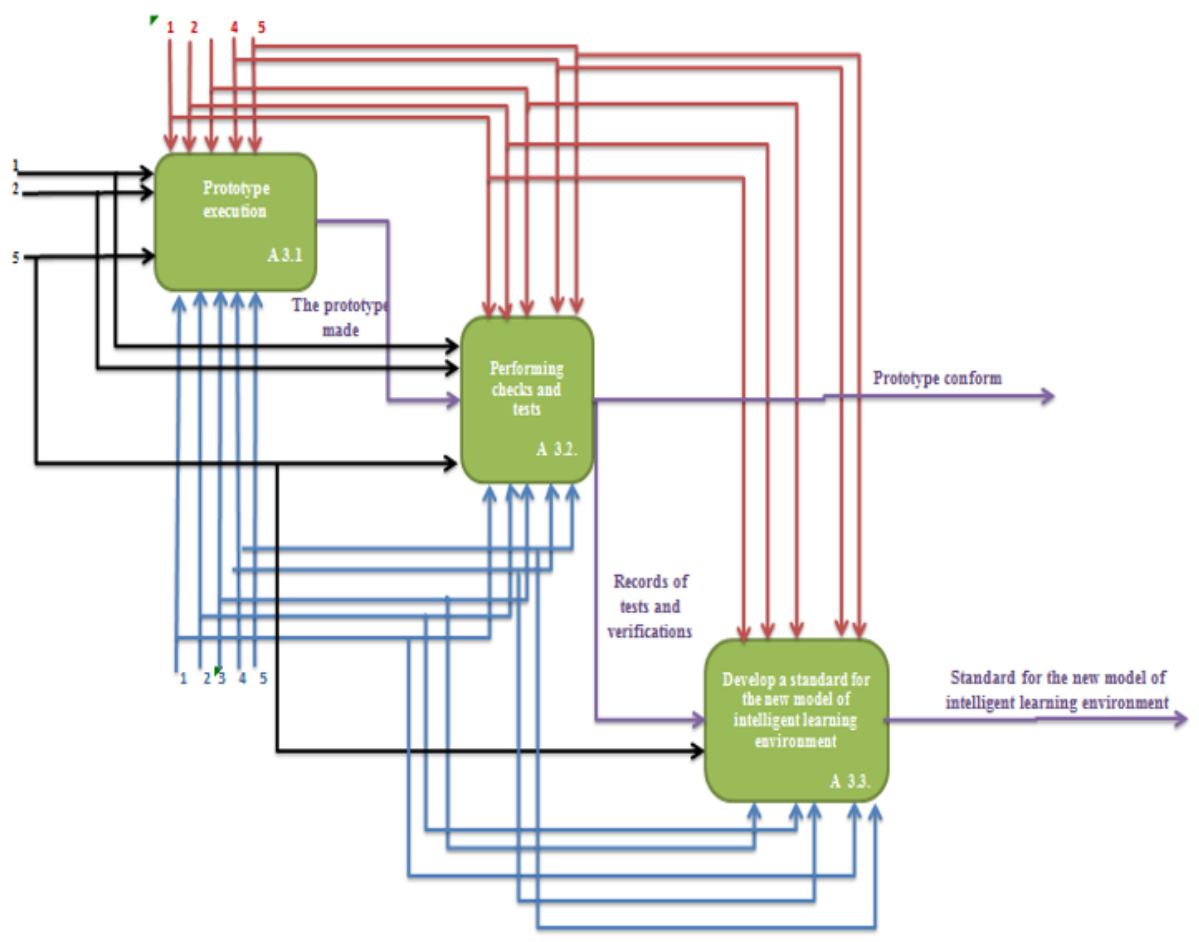

\section{Legends}

\section{No.crt. Input data}

1 Student requirements

2 Teacher requirements

3

4

5 Parental requirements

Fig.5. Prototype execution

\section{Control elements Mechanisms}

Legal regulations Procedures / instructions Internal regulations Personal

Managerial policies Material resources

Other regulations

Management

systems
Financial resources

Infrastructure / equipment 


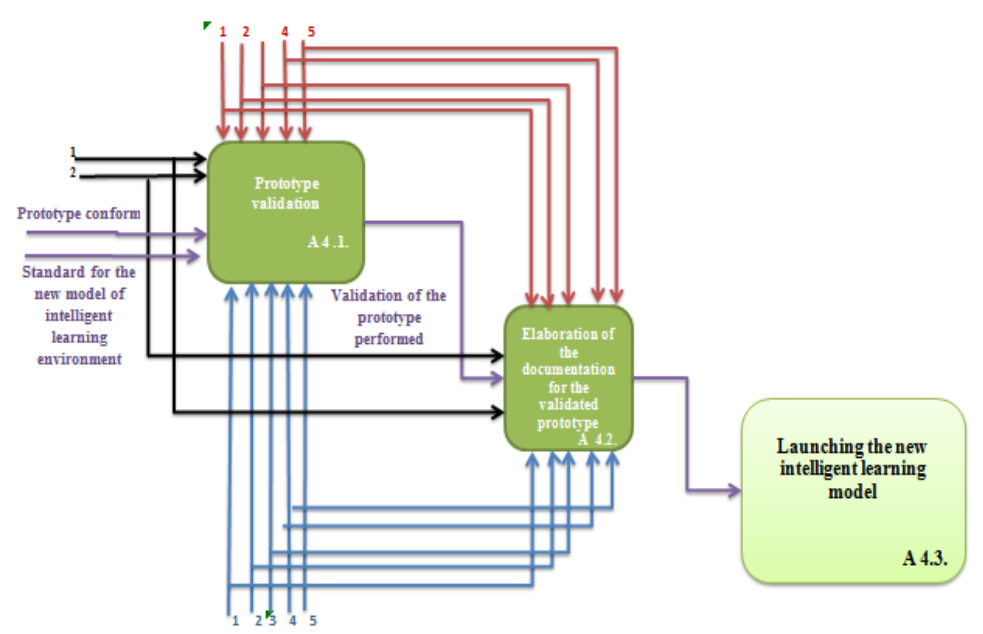

Legends

\begin{tabular}{ll}
$\begin{array}{l}\text { No. } \\
\text { crt. }\end{array}$ & Input data \\
1 & \\
2 & Student requirements \\
3 & Teacher requirements \\
4 & \\
5 & \\
\hline
\end{tabular}

\section{Control elements}

Legal regulations Internal regulations Managerial policies Other regulations Management systems

\section{Mechanisms}

Procedures / instructions

Personal

Material resources

Financial resources

Infrastructure / equipment

Fig. 6. Prototype validation

\section{Discussion}

An intelligent learning environment should support planning and innovative alternatives even more if results are desired. This could include functions to promote engagement, effectiveness and efficiency [22]. Such traits are inspired by the human interpretation of intelligent traits. In addition, a laerning environments to what a student knows, masters and wishes to continue learning can be considered intelligent, as can a person making reasonable adjustments to activities and activities given the constraints of a student's situation [22].

Since this study was limited to exploring the relevant literature, future studies could define aspects that lead to an intelligent learning environment resulting from quantitative research based on two techniques ( eg, a questionnaire and behavioral mapping sessions). Other considerations could include a tool for evaluating classrooms at a university to see the results compared to this study.

\section{Conclusion}

The result of this research is a conceptual model based on studies from the literature, that can be used to develop an intelligent learning environment. The realized prototype can be seen as intelligent, as, according to the literature examined, it comprises all three dimensions that are specific to an intelligent learning environment. Research in the literature shows that a learning environment has a significant impact on student's academic 
performance.The three specific dimensions of an intelligent learning environment have provided researchers with essential elements that can help meet student's environmental needs, particularly with regard to the receptive social environment and controlled environmental conditions. In future research studies, we also suggest disseminating the model using the dynamic modeling process and then the model will be piloted for final validation in both physical and virtual environment.

I think it is especially important to understand how to design a learning environment for students, because in his academic life there are many variables that affect his performance, such as: home environment, virtual environment and classroom environment.

\section{References}

1. P. Baepler, J.D.Walker, Active Learning Space, New directions for Teaching and Learning, Active learning classrooms and educational alliances: Changing relationships to improve learning, ,137, 27 -40 (2014)

2. R.G. Carpenter, Hershey PA: IGI Global, Cases on higher education spaces: Innovation, collaboration and technology,377, (2013)

3. K.J. Metzger, Bioscene, Collaborative teaching practices in undergraduate active learning classrooms: A report of faculty team teaching models and student reflections from two biology courses, 41(1), 3-9, 2015

4. P.H.P. Chiu, S.H. Cheng, Bioscene: Journal of College Biology Teaching, Effects of active learning classrooms on student learning: two -year empirical investigation on student perceptions and academic performance, Higher Education Research \& Development,36(2), 269-279, (2017)

5. S. Painter, The Perry Chapman Prize: Society for College and University Planning, Research on learning space design: Present state, future directions, (2013)

6. T. Byers, W. Imms, E. Hartnell - Young, Curriculum and Teaching, Making the Case for Space: The effect of Learning Spaces on Teaching and Learning, 29 (1), 5-19,(2014)

7. R.Talbert, A. Mor-Avi, Heliyon, A space for learning: An analysis of research on active learning spaces, (2019)

8. K. S. Noh, S., Ju. H. Jung, , Journal of Digital Policy \& Management, An exploratory study on concept and realization condition of smart learning,9 (2), 79-88 (2011)

9. G.Cebrian, R. Palau, J. Mogas,Sustainability, The Smart Classroom as a Means to the Development of ESD Methodologies, (2020)

10. P. Kirschner, J.J.G. Van Merrienboer, Do Learners Really Know Best? Urban Legends in Education, Educational Psychologist, 48 (3), 169 - 183, (2013)

11. R.Palau, J. Mogas, In Propuestas Multidisciplinares de Innovacion Educativa, Systematic literature review for a characterization of the smart learning environments, 55-71, (2019)

12. R. Koper, Smart Learn. Environ,Conditions for effective smart learning environments, (2014)

13.Z.T. Zhu, M.H. Yu, P. Riezebos, Smart Learn. Environ, A research framework of smart education, (2016)

14. J.M. Spector,Smart Learn. Environ, Conceptualizing the emerging field of smart learning environments, (2014)

15. J.K. Price, Smart, Learn. Environ., Transforming learning for the smart environment: Lessons learned from the Intel education initiatives, (2015).

16. Z.Ting Zhu, M. Hua Yu, P. Riezebos, Smart Learn. Environ, A research framework of smart education, (2016). 
17. B. Gros, Smart Learn. Environ. ,The design of smart educational environmets, 3(1), 1525,(2016)

18. T. Hoel, J. Mason, Smart Learn. Environ., Standards for smart education-Towards a development framework, 5 (1), 3-27, (2018)

19. D. Zhicheng, S. Chengzhang, Z.Liang, L. Zhi, IEEE Access, Assessment of Smart Learning Environmets in Higher Educatonal Institutions: A Study Using AHP-FCE and GA-BP Methods, (2021)

20. A.Rowe, Springer, Feelings about feedback: The role of emotions in assessment for learning. In Scaling up assesment for learning in higher education, 159-172, (2017)

21. A.Rowe, J. Fitness, Behavioral Sciences, Understanding the role of negative emotions in adult learning and achivement: A social functional perspective, 8(2), (2018)

22.Z. Papamitsiou, A.A. Economides, Learning, Design and Technology,Learning Analytics for Smart Learning Environmets: A Meta- Analysis of Empirical Research from 2009 to 2015, 1-23, (2015). 